\title{
A research on particle board factory by utilization of integer linear
}

\section{programming}

\author{
Yunus SAHIN ${ }^{1}$, Hasan SERIN ${ }^{1 *}$ \\ ${ }^{1}$ Kahramanmaraş Sütçü İmam University, Faculty of Forestry, Kahramanmaras, TURKEY \\ *Corresponding author: hasanserin@ksu.edu.tr
}

Received Date: 13.01.2017

Accepted Date: 26.05 .2017

\section{Abstract}

Aim of study: There are some factors which effect production of establishments for instance; quality, cost, time, capacity of production, raw material, market structure, and, customer variables. The establishments have to perform their productive activity in accordance with these variables for minimum cost or maximum profit. Therefore, it is necessary to make a production planning for doing something at correct time. While making the production planning, quantitative determine techniques are used for solving of complex problems. The linear programming which is the best among the quantitative techniques provides active and optimum production planning.

Area of study: This study was conducted at the particle board factory, located on the Mersin city, Turkey.

Material and Methods: In this research, particle board factory and its production process were examined. The linear programming method was run on LINGO 13.0 programme.

Main results: In this study, it was determined that particle board production quantity, particle board stock quantity for a year. The demand was covered completely. 1000 number demand at production of particle board were covered with stock product by different production quantities in particular months.

Research highlights: Development of the firms on this way will lead to further in terms of economic of country and its development.

Keywords: Linear programming, Production planning, Cost, Forestry

\section{Yonga levha fabrikasında doğrusal programlama kullanımı üzerine}

\section{bir araştırma}

Özet

Çalışmanın amacı: İşletmelerin üretimini etkileyen faktörler; fiyat, kalite, zaman, üretim kapasitesi, hammadde, piyasa yapısı ve müşteri değişkenleridir. İşletmeler üretim faaliyetlerini bu değişkenler doğrultusunda minimum maliyet ya da maksimum kar amacına yönelik yürütmek durumundadırlar. $\mathrm{Bu}$ sebeple yukarıda sayılan faktörler bakımından nelerin, nerelerde, kimler tarafindan, ne zaman ve nasıl yapılacağına ilişkin bir üretim planı yapılması gerekmektedir. Üretim planlanması yapılırken ortaya çıkabilecek karmaşık sorunların çözümünde kantitatif karar verme teknikleri kullanılır. Bu tekniklerin başında gelen doğrusal programlama metodu, yapılan üretim planının etkin ve optimum olmasını sağlar.

Çalışma alanı: $\mathrm{Bu}$ çalışma Türkiye'nin Mersin ilinde yer alan yonga levha fabrikasında gerçekleştirilmiştir.

Materyal ve Yöntem: Yapılan çalışmada yonga levha fabrikası ve bu fabrikanın üretim yöntemi incelenmiştir. Lineer program metodu LINGO 13.0 üzerinde çalıştırılmıştır.

Sonuçlar: Bu çalışmada, yıllık olarak yonga levha üretiminin miktarı ve yonga levha stok miktarı belirlenmiştir. Talep tamamıla karşılanmıştır. 1000 sayıda yer alan üretimdeki talep kısmi olarak aylarda farklı üretim miktarlarıyla stok üretimi ile karşılanmıştır.

Araştırma vurgulart: $\mathrm{Bu}$ yöntem ile işletmelerdeki gelişme sayesinde sürdürülebilirlikleri devam edecek ayrıca ülke ekonomisi ve kendi ekonomilerine büyük katkı sağlayacaktır.

Anahtar Kelimeler: Doğrusal Programlama, Üretim Planlama, Maliyet, Ormancılık 


\section{Introduction}

The production of board which has a wood-based homogeny structure has started in 1940s. Particleboard and fibreboard industries have established in Turkey, 1950s. Particularly, these industries have rapidly developed after the Second World War, because it has been in need of large scale materials for working on restructuring of cities. Particleboard, constitutes dried wood chips which are glued together with a resin which cures under the influence of high pressure and heat. Wood chips are derived from wood raw materials, such as round wood, sawdust, shavings, flakes, and recovered wood from various sources.

Particle board is used in furniture, forestry enterprises, glue industry, timber factories, paper sector, construction, decoration, energy sector, and other fields. Particle boards have many mechanical and physical characteristics (Akbulut, 2000);

- Smooth surface and it can be produced all thickness,

- Homogeny structure and it can be joined with nail, screw, and glue,

- It provides saving from labour because of it's produced large sizes,

- It can be applied top surface process,

- It can get new characteristics by treating with hydrophobic, protector, and fire-retardant materials,

- It can be handed easily and it has not defects such as knot, decay, and fibre curvature in solid wood panels also it is cheap.

Quantitative research is an approach for testing objective theories by examining the relationship among variables (Crotty, 1998).
The objective of quantitative research is to develop and employ mathematical models, theories and hypotheses pertaining to phenomena. A mathematical model is a description of a system using mathematical concepts and language. Mathematical models are used in natural sciences (physics, biology, chemistry, etc.), social sciences (economics, sociology, political science, etc.), and engineering disciplines (computer science, artificial intelligence, etc.) (Wayne, 1994).

Mathematical models can take many forms, including linear programming, statistical models, game theoretic models, etc. Linear programming (LP) is a method to achieve the best outcome such as maximum profit or lower cost (Chase, et al 2001). This programme is a widely used field of optimization several reasons. Many practical problems in operation research can be expressed as linear programming. LP provided a basis for stochastic, non-linear programming, and so on (Morris, 1967).

Linear programming is heavily used in microeconomics and company management, such as planning, production, transportation, technology, and other issues. A research on Fortune 500, which is big company among the biggest companies in America, was determined that $85 \%$ of firms used linear programming at decision making process (Büyükkeklik, 2007).

Linear programming has 3 basic factors: objective function, constraints, and nonnegative variables (Özsan, 2006). Objective function is generally established up suitable for maximum profit and/or minimum cost.

- Objective function of maximum problems;

$$
\mathrm{Z}_{\max }=\sum_{j=1}^{N} X j c j \quad(j=1,2, \ldots \ldots N)
$$

Objective function of minimum problems;

$$
\mathrm{Z}_{\mathrm{min}}=\sum_{j=1}^{N} X j c j \quad(j=1,2, \ldots \ldots N)
$$

- Constraints, which use in linear programming, are demonstrated at below:

At maximum problems;

$$
\sum_{i=1}^{M} \quad \sum_{j=1}^{N} \text { Xjaij } \leq b i \quad(j=1,2, \ldots \ldots N i=1.2 \ldots \ldots, M)
$$

At minimum problems,

$$
\sum_{i=1}^{M} \quad \sum_{j=1}^{N} \text { Xjaij } \geq b i \quad(j=1,2, \ldots \ldots N i=1.2 \ldots \ldots, M)
$$

- Decision variables must be positive (Non-negative condition, $X_{j} \geq 0$ ). 
In this study, it was determined that particle board production quantity, particle board stock quantity for a year by using linear programming method at particle board factory.

\section{Material and Method \\ Material}

In this research, particle board factory and it's production process were examined. It was intended that the production of firm was in optimal level. The employers work 26 days in a month so work power is 37440 minutes. The production quantity $\left(\mathrm{m}^{3}\right)$ of particle board was determined in reference to months (Table 1).

As shown at Table 2 the machines and number of operators were determined on production process. Time is important factor at production process. The time spent at production was determined at Table 3 .

\section{Method}

The linear programming method was run on LINGO 13.0 programme. Demands for particle board (covered and uncovered) were 7500 and 1000 number every month in a year, respectively. Beginning product quantity was zero for all products. In this production system, sanding and melamine covering machine were narrow pass. It was ignored that the machines stop in maintenance and failure situation. The developed model was determined according to data and constraints;

$\mathrm{Z}_{\max }=\mathrm{TG}-(\mathrm{SM}+\mathrm{STM}+\mathrm{EASM}+\mathrm{EAKM})$
Table 1. The production quantity of particle board material $\left(\mathrm{m}^{3}\right)$ in reference to months

\begin{tabular}{lrrc}
\hline Months & \multicolumn{2}{c}{ Production } & $\begin{array}{c}\text { Number of } \\
\text { Worked Day }\end{array}$ \\
\cline { 2 - 3 } & $\mathrm{m}^{3}$ & $\mathrm{~m}^{3} /$ Day & \\
\hline January & - & - & 31 \\
\hline February & 9.148 & 326.71 & 28 \\
\hline March & 8.506 & 274.38 & 31 \\
\hline April & 2.932 & 97.73 & 30 \\
\hline May & 5.245 & 169.19 & 31 \\
\hline June & 5.355 & 178.50 & 30 \\
\hline July & 5.258 & 169.61 & 31 \\
\hline August & 4.615 & 148.87 & 31 \\
\hline September & 9.681 & 322.7 & 30 \\
\hline October & 3.569 & 115.12 & 31 \\
\hline November & 10.735 & 357.83 & 30 \\
\hline December & 10.464 & 337.54 & 31 \\
\hline TOTAL & 75.508 & 206.87 & 365 \\
\hline
\end{tabular}

Table 2. The machines and number of operators

\begin{tabular}{|c|c|c|c|}
\hline $\begin{array}{l}\text { Machine } \\
\text { No }\end{array}$ & Machine & $\begin{array}{l}\text { Machine } \\
\text { Quantity }\end{array}$ & $\begin{array}{l}\text { Number } \\
\text { of } \\
\text { Operator }\end{array}$ \\
\hline 1 & Chipping & 2 & 4 \\
\hline 2 & Dryer & 1 & 2 \\
\hline 3 & Sifter & 2 & 2 \\
\hline 4 & Layer & 1 & 1 \\
\hline 5 & Press & 1 & 2 \\
\hline 6 & Sanding & 1 & 2 \\
\hline 7 & $\begin{array}{l}\text { Melamine } \\
\text { Covering }\end{array}$ & 1 & 2 \\
\hline 8 & Packaging & 1 & 2 \\
\hline
\end{tabular}

Table 3. The time spent at production process

\begin{tabular}{clcc}
\hline \multirow{2}{*}{ Machine No } & \multirow{2}{*}{ Machine } & \multicolumn{2}{c}{ Production Times } \\
\cline { 3 - 4 } & & Particle (Uncovered) & Particle (Covered) \\
\cline { 3 - 4 } & & Minute/Number & Minute/Number \\
\hline 1 & Layer & 3.5 & 3.5 \\
\hline 2 & Press & 2.1 & 2.1 \\
\hline 3 & Sanding & 2.4 & 2.4 \\
\hline 4 & Melamine Covering & - & 3.1 \\
\hline 5 & Packaging & 2.5 & 2.5 \\
\hline
\end{tabular}

\section{Results}

The enterprise thought two products as uncovered particle board $(\mathrm{Y})$ and covered particle (YL) board at production system.
After using the LINGO package programme, outputs of the model were gained. These outputs were showed at tables. 
Table 4. Number of particle board quantity (Uncovered-Y)

\begin{tabular}{ccccccccccccc}
\hline $\begin{array}{c}\text { Machine } \\
\text { No }(\mathrm{j})\end{array}$ & 1 & 2 & 3 & 4 & 5 & 6 & 7 & 8 & 9 & 10 & 11 & 12 \\
\hline 1 & 1325 & 1323 & 1009 & 0 & 996 & 1752 & 2100 & 2098 & 0 & 0 & 0 & 0 \\
\hline 2 & 1325 & 1323 & 355 & 1001 & 996 & 1752 & 358 & 1513 & 1046 & 0 & 1831 & 0 \\
\hline 3 & 1002 & 1001 & 1000 & 1001 & 996 & 1752 & 358 & 1000 & 1559 & 0 & 979 & 1200 \\
\hline 4 & & & & & & & & & & & & \\
\hline 5 & 1000 & 1000 & 1000 & 1000 & 1000 & 1000 & 1000 & 1000 & 1000 & 1000 & 1000 & 1100 \\
\hline
\end{tabular}

As given at Table 4, there was particle board (Y) production table. Particle board demand quantities were given at production line monthly in a year. The demand was covered completely. 1000 number demand at production of particle board were covered with stock product by different production quantities in particular months. There were some 0 values at Table 4 because the firm covered the demand it's stock product at this month.

Table 5. Number of stock particle board (YSS)

\begin{tabular}{ccccccccccccc}
\hline $\begin{array}{c}\text { Machine } \\
\text { No (j) }\end{array}$ & 1 & 2 & 3 & 4 & 5 & 6 & 7 & 8 & 9 & 10 & 11 & 12 \\
\hline 1 & 0 & 0 & 651 & 0 & 0 & 0 & 1742 & 2277 & 1581 & 1581 & 100 & 100 \\
\hline 2 & 323 & 645 & 0 & 0 & 0 & 0 & 0 & 513 & 0 & 0 & 850 & 0 \\
\hline 3 & 2 & 3 & 3 & 4 & 0 & 752 & 110 & 110 & 669 & 19 & 0 & 100 \\
\hline 4 & & & & & & & & & & & & \\
\hline 5 & 0 & 0 & 0 & 0 & 0 & 0 & 0 & 0 & 0 & 0 & 0 & 100 \\
\hline
\end{tabular}

There were stocks between the production machines within production time of particle board in some months. It was seen that the stock quantities went back to acceptable stock level at last of year. As given at Table
5, there was 100 number of stock at last of year and it provided stock constraint that was maximum 1000 number stock.

Table 6. Number of covered particle board quantity (YL)

\begin{tabular}{ccccccccccccc}
\hline $\begin{array}{c}\text { Machine } \\
\text { No }(\mathrm{j})\end{array}$ & 1 & 2 & 3 & 4 & 5 & 6 & 7 & 8 & 9 & 10 & 11 & 12 \\
\hline 1 & 7505 & 9842 & 0 & 6648 & 9 & 0 & 8151 & 0 & 8035 & 0 & 0 & 0 \\
\hline 2 & 7500 & 8992 & 8855 & 6647 & 7 & 8 & 8150 & 9131 & 10004 & 0 & 0 & 0 \\
\hline 3 & 7500 & 8992 & 8 & 9994 & 0 & 9 & 8150 & 6662 & 10004 & 9759 & 1542 & 0 \\
\hline 4 & 7500 & 8992 & 8 & 7500 & 8993 & 7 & 7500 & 7500 & 7500 & 9759 & 1542 & 7500 \\
\hline 5 & 7500 & 7500 & 7500 & 7500 & 7500 & 7500 & 7500 & 7500 & 7500 & 7500 & 7500 & 7600 \\
\hline
\end{tabular}

Covered particle board demand quantities were given at production line monthly in a year (Table 6). There were some 0 values at
Table 6 because the firm covered the demand its stock product at this month. Also successive 0 values showed that the firm produced 1000 number production monthly.

Table 7. Number of stock covered particle board (YLSS)

\begin{tabular}{cccccccccccccc}
\hline $\begin{array}{c}\text { Machine } \\
\text { No (j) }\end{array}$ & 1 & 2 & 3 & 4 & 5 & 6 & 7 & 8 & 9 & 10 & 11 & 12 \\
\hline 1 & 5 & 5855 & 0 & 0 & 2 & 0 & 1742 & 2277 & 1581 & 1581 & 100 & 100 \\
\hline 2 & 0 & 0 & 8847 & 1 & 7 & 0 & 0 & 513 & 0 & 0 & 850 & 0 \\
\hline 3 & 0 & 0 & 0 & 2494 & 0 & 752 & 110 & 110 & 669 & 19 & 0 & 100 \\
\hline 4 & 0 & 1492 & 0 & 0 & 0 & 0 & 0 & 0 & 0 & 7500 & 0 & 0 \\
\hline 5 & 0 & 0 & 0 & 0 & 0 & 0 & 0 & 0 & 0 & 0 & 0 & 100 \\
\hline
\end{tabular}


It was determined that the stock quantities were occurred within a year plan during the production of covered particle board. As given at Table 7, there was 100 number of stock at last of year and it provided stock constraint that was maximum 1000 number stock. For instance; 1-2-3-5-11th months had 0 value at 3 number machine, 1-3-4-5-6-7-89-11-12th months had 0 value at 4 number machine because there was not stock requirement at these months.

\section{Discussions}

Covered particle board and uncovered particle board covered demands and quantity of uncovered demand (TKM) was zero (Table4 and Table 6). Because these particle boards produced enough level and the firm had adequate stock quantity. The firm arranged stock cost to production rate after that the stock cost reduced.

As a result, the firm covered the demand of customer properly by working on suitable conditions. The firm will get over with using sources properly and customer satisfaction. After this done research, sustainability of the firm will increase by optimal approaches and it will provide competitive advantage. Development of the firms on this way will lead to further in terms of economic of country and its development.

\section{References}

Akbulut, T. (2000). Yonga Levha Endüstrisi, Laminart Mobilya Dekorasyon Sanat Tasarım Dergisi, Nisan-Mayıs, 7, 112119.

Büyükkeklik, M. (2007). “Üretim Planlama Problemlerinde Doğrusal Programlama Modelinin Kullanımı: 'Bir Üretim İşletmesinde Uygulama', Yüksek Lisans Tezi, 40.

Chase, R. B. ve Aqilano N. J. ve Jacobs F. R. (2001). Operations Management For Competitive Advantage, New York: The McGraw-Hill Companies.

Crotty, M. (1998). The foundations of social research: Meaning and perspective in the research process. Thousand Oaks, CA: Sage.

Morris, W. (1967). " On the Art of Modeling." Management Science, Vol. 13, B707-B717.

Özsan, Ö. (2006). Mermer işletme tesislerinde ürün miktarının doğrusal programlama tekniği yardımı ile belirlenmesi. Yüksek Lisans Tezi İzmir, 15.

Wayne, L. W. (1994). "Operations Research: Applications and Algorithms", International Thomson Publishing, 151153. 